\title{
Modeling tolerant hardwood sapling density and occurrence probability in the Acadian forests of New Brunswick, Canada: Results 14 years after harvesting
}

\author{
by Mohammed Henneb ${ }^{1,2}$ *, Gaetan Pelletier², Mathieu Fortin ${ }^{1}$, Nelson Thiffault ${ }^{1}$ and Marie-Andrée Giroux ${ }^{1}$
}

\begin{abstract}
Natural forest regeneration after natural or anthropogenic disturbance is difficult to predict given its high variability. The process is poorly documented for commercial northern hardwood species in the Acadian forest of eastern Canada. Our objective was to identify the silvicultural, environmental, and ecological factors that best explain the variability in sapling density and occurrence of two commercial tolerant hardwood species in New Brunswick: American beech (Fagus grandifolia Ehrh.) and sugar maple (Acer saccharum Marsh.). Forty-three permanent sample plots were established in 2002 and measured before harvesting in 2004. Sapling density and occurrence were measured 14 years after harvesting. The results showed that the interactions between the species and the residual merchantable basal area and between the species and the percent of hardwoods in the original stand best explained the sapling density and occurrence variation of tolerant hardwoods. The sapling density of sugar maple increased with increasing merchantable residual basal area. However, the effect of this variable was not significant for the density of American beech saplings. The density and occurrence of tolerant hardwood saplings both increased along with the percent of hardwoods in the original stand. These results provide an improved understanding about tolerant hardwood regeneration dynamics in New Brunswick forests.
\end{abstract}

Keywords: Acadian forest, tolerant hardwoods, sapling density, occurrence probability, regeneration modeling

\section{RÉSUMÉ}

Il est difficile de prévoir la régénération naturelle de la forêt à la suite d'une perturbation d'origine anthropique puisqu' elle est hautement variable. Le processus est mal documenté dans les essences feuillues des forêts commerciales de la forêt acadienne de l'est du Canada. Nos travaux avaient pour but de trouver les facteurs sylvicoles, environnementaux et écologiques qui permettraient d'expliquer la variabilité de la présence et de la densité des gaules chez deux essences de feuillus tolérants commerciaux au Nouveau-Brunswick : le hêtre à grandes feuilles (Fagus grandifolia Ehrh.) et l'érable à sucre (Acer saccharum Marsh.). En 2002, nous avons donc établi quarante-trois placettes permanentes et les avons mesurées avant l'opération de récolte 2004. Quatorze ans après cette coupe, nous sommes retournés mesurer la densité et la présence des gaules. Les résultats nous indiquent que ce sont la relation entre l'essence et la surface terrière résiduelle, et celle liant l'essence au pourcentage de feuillus du peuplement original qui expliquent le mieux les variations dans la densité et la présence de gaules de feuillus tolérants. La densité des gaules d'érable à sucre avait tendance à augmenter avec une augmentation de la surface terrière marchande. Toutefois, l'effet de cette variable ne s'est pas avéré significatif pour la densité des gaules de hêtre à grandes feuilles. La densité et la présence des gaules de feuillus tolérants ont toutes les deux crû avec le pourcentage de feuilles dans le peuplement original. Ces résultats ont permis d'améliorer nos connaissances sur la dynamique de la régénération chez les feuillus tolérants dans les forêts du Nouveau-Brunswick.

Mots-clés: Forêt acadienne, feuillus tolérants, densité des gaules, probabilité de présence, modélisation de la régénération

\footnotetext{
${ }^{1}$ K.-C.-Irving Research Chair in Environmental Sciences and Sustainable Development, Université de Moncton, 18 avenue AntonineMaillet, Moncton, NB E1A 3E9, Canada. * Corresponding author (mohammed.henneb@hardwoodsnb.ca)

${ }^{2}$ Northern Hardwood Research Insitute Inc., 165 boul. Hébert, Edmundston, NB E3V 2S8, Canada

${ }^{3}$ Natural Resources Canada, Canadian Forest Service, Canadian Wood Fibre Centre, 580 Booth Street, Ottawa, ON K1A 0E4, Canada

${ }^{4}$ Natural Resources Canada, Canadian Forest Service, Canadian Wood Fibre Centre, 1055 rue du PEPS, P.O. Box 10380, Stn Sainte Foy, QC G1V 4C7, Canada
} 


\section{Introduction}

Regeneration is an important process shaping forest dynamics because it directly influences the future composition and productivity of forest stands (MacDonald and Thompson 2003; MacDonald et al. 2004; Man et al. 2010). The forest regeneration process is the ability of a stand to renew spontaneously after natural or anthropogenic disturbance (Carle and Holmgren 2003) by establishing new cohorts. This process is difficult to predict, given its high variability (Li et al. 2011) and the influence from several factors such as the physiological characteristics of the species, ecological and soil conditions, and disturbances (Kozlowski 2002; MacDonald et al. 2004; Bataineh et al. 2013; Nelson and Wagner 2014). Some studies have proposed various models for regeneration predictions based on one or several predictor variables such as disturbance intensities, stand basal area (before and after harvesting), environmental conditions of the site, seed dispersal and parent tree location, and the initial composition of the stand (Ribbens et al. 1994; Liu and Ashton 1998; Hanson et al. 2011; Klopcic et al. 2012; Danyagri et al. 2017, 2019). However, these models have some limits related to their low accuracy and their inability to explain the complexity of the regeneration process (Hanson et al. 2011; Klopcic et al. 2012), and in some cases, related to limited data availability (Hanson et al. 2011).

In the Acadian forest region of North America, understanding the factors that determine the density and occurrence of regeneration of tolerant hardwood species in space and time has always been a concern for forest managers. The patterns of forest regeneration for commercial northern hardwood species (Li et al. 2011; Nelson et al. 2013) represent an important knowledge gap, and this situation will continue and perhaps worsen, given the anticipated climate change that will bring an additional share of uncertainty and complexity. Modifications in the patterns of temperature, precipitation, and the occurrence and intensity of extreme weather events are expected (Dullinger et al. 2004; Dore 2005; Kirilenko and Sedjo 2007). For Atlantic Canada's forests, these climate changes will likely affect the regeneration of tree species. The distribution of native tree species in this region is expected to shift with climate change as it lies in the transition zone between the temperate and the boreal biomes (Chapin et al. 2004; Williamson et al. 2009). Furthermore, the Acadian Forest Region of Canada might face a temporary decrease in forest growth and wood supply by the end of the 21 st century due to climate change (Taylor et al. 2017). In addition to such predictions, some studies showed that harvest intensity influences the composition of regeneration in hardwood forests (Danyagri et al. 2017). For example, in hardwood stands, partial harvesting is preferred to clearcutting since it favours the regeneration of tolerant species (Jenkins and Parker 2001; Angers et al. 2005) and allows for the production of good quality saw timber (Leak and Sendak 2002). Edaphic conditions may also influence the composition of the regeneration in hardwood stands (Coates and Burton 1997), although the effects of partial harvesting on soils are variable (Beaudet et al. 2002).

Tolerant hardwood species such as sugar maple (Acer saccharum Marsh.) and American beech (Fagus grandifolia Ehrh.) often grow together and they count among the most common hardwood species in the Acadian forest region
(Seymour et al. 2002). In this region, the stands dominated by tolerant hardwoods have important ecological and economic interests, since they contribute to ecosystem complexity at the landscape scale, provide habitat for many wildlife species and supply a variety of forest products (Betts et al. 2003; Etheridge et al. 2005). Nevertheless, the current economic value of American beech is much lower than that of sugar maple, which is managed for the production of high value appearance wood products used in flooring, furniture and cabinetmaking (Havreljuk et al. 2014). In addition, increasing American beech abundance might perpetuate beech bark disease in forest stands and substantially reduce its economic and ecological values (Griffin et al. 2003; Hane 2003; Loo and Ives 2003). With climate change, it is expected that the percent of American beech and red maple (Acer rubrum L.) will increase to the detriment of sugar maple (Taylor et al. 2017).

Arguably, predicting regeneration dynamics is one of the most complex tasks in forest modeling (Spence and MacLean 2012; Danyagri et al. 2017). After decades of research, it remains challenging to predict the impact of several factors on forest regeneration in the Acadian forest of North America (Li et al. 2011; Salmon et al. 2016). Predicting the effects of silvicultural, environmental and ecological factors on sapling density of tolerant hardwoods is a challenging task due to the complexity of the processes involved and the limited availability of data in this region. Adequate wood supply calculations requires the prediction of sapling dynamics of commercial hardwood species in order to practice sustainable forest management (Beyeler 2002; Bose et al. 2014).

The objective of this study was to identify the silvicultural, environmental, and ecological factors that best explain variations in sapling density and occurrence probability of two commercial tolerant hardwood species (American beech, sugar maple) in New Brunswick, Canada. We first predicted that the variation in sapling density and occurrence probability is best explained by treatment intensity expressed as the percent of merchantable basal area removed during harvesting. We also predicted that sapling density and occurrence of sugar maple were favoured by the highest treatment intensity, contrary to the sapling density and occurrence of American beech.

\section{Materials and methods Study area}

The study area is located in the Black Brook District ( 200000 ha) owned by J.D. Irving Limited in northwestern New Brunswick, Canada (Fig. 1). The regional climate (Central Uplands Ecoregion) is cold with relatively abundant precipitation (Zelazny et al. 2007). The mean annual precipitation is $1104 \mathrm{~mm}$; mean annual temperature is $3.5^{\circ} \mathrm{C}$ and mean growing degree days above $5^{\circ} \mathrm{C}$ is 1532.6 (Environment and Climate Change Canada 2020). The forest stands in the study area have complex structures and are composed of a mixture of hardwood and softwood species (Hennigar et al. 2016). They are dominated by American beech, sugar maple and yellow birch (Betula alleghaniensis Britt.). Other hardwood species such as red maple, white birch (Betula papyrifera Marsh.) and poplar (Populus spp.) are found in low proportions. The most common softwood species in these stands are balsam fir (Abies balsamea (L.) Mill.), black spruce (Picea mariana (Mill.) BSP), white spruce (Picea 


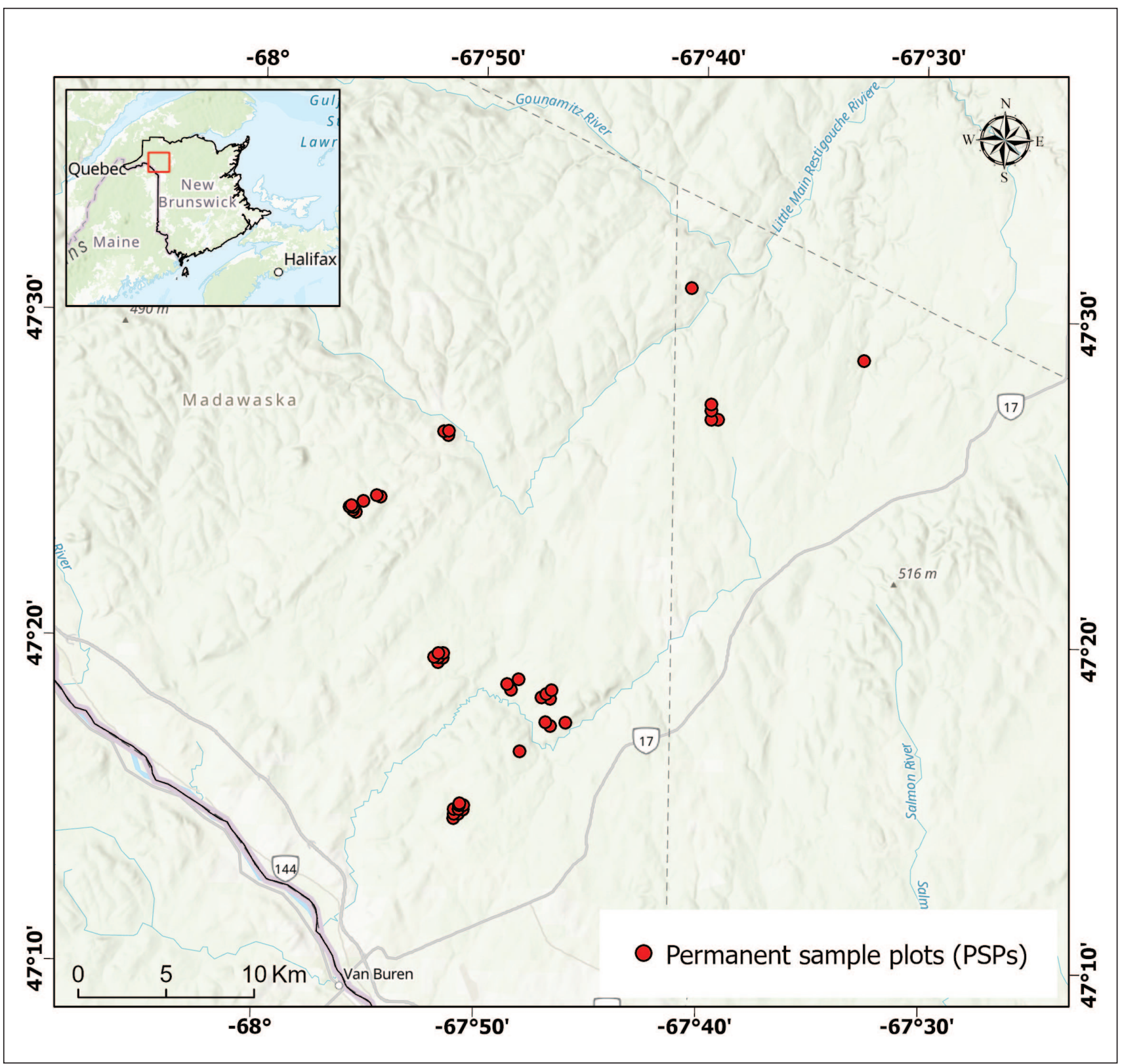

Fig. 1. Location of the study area (red square) in Eastern Canada and distribution of the permanent sample plots (PSPs) within the study area.

glauca (Moench) Voss) and red spruce (Picea rubens Sarg.). These species are found in proportions and associations that vary according to the local climate, soil fertility, topography and local disturbances (Erdle and Pollard 2002).

\section{Experimental design and data collection}

We used data collected in 43 permanent sample plots (PSPs) of 0.05 ha randomly distributed in the Black Brook District (Fig. 1). These PSPs are part of a network of plots that have been used in several studies to evaluate the regeneration rates of commercial tree species before and after different harvest treatments (Maclean et al. 2010; Dracup and MacLean 2018). The PSPs were established and measured in 2002 before har- vesting. The merchantable cohort in the original stands was dominated by softwoods, with a density of merchantable trees $(\mathrm{DBH}>9.1 \mathrm{~cm})$ ranging between 20 and 3720 trees ha $^{-}$ ${ }^{1}$ (Fig. S1, Appendix 1). However, the merchantable basal area of sugar maple, ranging from 0.82 to $40.18 \mathrm{~m}^{2} \mathrm{ha}^{-1}$ (mean = $17.33 \mathrm{~m}^{2} \mathrm{ha}^{-1}$ ), was higher than other species or group of species (Fig. S2, Fig. S3, Appendix 1).

In 2004, the study area was treated using different harvest intensities expressed as the percent of merchantable basal area removed in each plot ranging between $11.6 \%$ and $95.8 \%$. Four categories of harvest intensity were created from the four quantiles of the percent of merchantable basal area removed data, low (basal area removed $\leq 25 \%$ ), medium 
(25\% basal area removed $\leq 50 \%)$, high $(50 \%$ basal area removed $\leq 67 \%)$ and very high $(67 \%$ basal area removed $\leq$ $96 \%)$. Balsam fir was heavily targeted by these harvest treatments in order to emulate a spruce budworm (Choristoneura fumiferana Clem.) outbreak and to create gaps in the stand. In the residual stands (after harvesting), the merchantable tree density and basal area of sugar maple (ranging from 20 to 740 trees $\mathrm{ha}^{-1}$, and from 0.24 to $31.78 \mathrm{~m}^{2} \mathrm{ha}^{-1}$, respectively), were higher than softwood and other commercial hardwood tree density (Fig. S1, Fig. S2, Fig. S3, Appendix 1). Tolerant hardwoods (American beech, sugar maple) were the most dominant in the original and residual stands compared to other hardwood species or groups (Fig. S1, Fig. S2, Fig. S3, Appendix 1).

In 2018, 14 years after harvesting, the density of commercial hardwood saplings (stems ha ${ }^{-1}$, regeneration with diameter outside bark at breast height (DBH; $1.3 \mathrm{~m}$ above ground) - between $1 \mathrm{~cm}$ and $9 \mathrm{~cm}$ ) was measured in each PSP. We conducted a complete census of saplings in each PSP. Silvicultural and ecological variables were collected or calculated for each PSP from existing inventory data. Environmental variables were extracted from geographical information system layers for each plot (all data from the Northern Hardwoods Research Institute, New Brunswick, Canada).

\section{Silvicultural and ecological variables}

All silvicultural and ecological variables were summarized for pre- and post-harvest stands. The silvicultural variables included the percent of merchantable basal area removed after the first harvest, the residual merchantable basal area $\left(\mathrm{m}^{2} \mathrm{ha}^{-1}\right)$, the percent of softwoods in the residual merchantable basal area, the percent of hardwoods in the residual merchantable basal area, and the quadratic mean diameters $(\mathrm{QMD}, \mathrm{cm})$ of the removed and residual merchantable trees after the first harvest. The ecological variables were associated with the original stand characteristics (before harvest). These variables included the total basal area of the original stand $\left(\mathrm{m}^{2} \mathrm{ha}^{-1}\right)$, the QMD of merchantable trees in the original stand before harvest, and the percent of the following species group in the merchantable basal area of the original stand: percent of softwood, hardwoods, tolerant hardwoods (American beech, sugar maple), mid-tolerant hardwoods (yellow birch, red maple) and intolerant hardwoods (white birch, trembling aspen).

\section{Environmental variables}

The environmental variables included forest ecosite, namely a stand-scale ecological classification unit that includes a series of site conditions influencing forest productivity in Acadian and maritime-boreal forests (Zelazny et al. 2007). The ecosite is an ecological basis used to group vegetation and soil types (Yang et al. 2017), depth of the water table (DWT, m), slope inclination (\%) and aspect, elevation (m) and topographic index (TPI), soil type, biomass growth index (BGI, $\mathrm{kg}^{-1} \mathrm{ha}^{-1} \mathrm{yr}^{-1}$ ). BGI is a forest productivity site index in the Acadian forest region (Hennigar et al. 2016). BGI values were extracted from a BGI map of the Acadian forest region in New Brunswick (data from the Northern Hardwoods Research Institute, New Brunswick, Canada).

\section{Statistical analyses}

To identify the silvicultural, ecological and environmental variables that best explained variations in sapling density and occurrence of tolerant hardwood species (American beech and sugar maple saplings), we compared a series of zeroinflated negative binomial (ZINB) models (function "zeroinfl", package "pscl" in R) (Jackman 2008; Zeileis et al. 2008). Several authors recommend using ZINB models for over-dispersed count data (e.g., sapling density) with extra zeros (Thomas et al. 2018; Aldirawi et al. 2019; Wang et al. 2020). In this case, the ZINB distribution is more appropriate for modeling count data compared to the commonly used Poisson distribution (Aldirawi et al. 2019). In addition, we used ZINB models because they can simultaneously predict the density and the occurrence probability of saplings, while modeling nonlinear effects of silvicultural, environmental, and ecological factors. A ZINB model relies on the joint distribution that combines a negative binomial probability mass function (PMF) and a binomial PMF. The former predicts the sapling count whereas the latter accounts for the excess of zero values. The means of the two PMFs are modelled through link functions (McCullagh and Nelder 1989) so that the predictors can enter the model linearly. More specifically, a logit link function was used in the binomial PMF whereas the negative binomial PMF implemented a log link function. This analytical approach has been used in several studies, notably in horticultural research, wildlife inventorying, and forest ecology to predict tree recruitment (Hall 2000; Cunningham and Lindenmayer 2005; Ripley et al. 2005; Fortin and DeBlois 2007).

A series of 104 candidate models were fitted in accordance with our research objectives (ecological concerns) and to provide silvicultural guidance to forest managers. The candidate models included different combinations of the predictors (silvicultural, ecological and environmental variables) and relevant interactions between these predictors. All candidate models are shown in Table S1, Appendix 1. In addition, we checked the goodness-of-fit for each model by examining the fitted values against actual values.

We selected the ZINB model that best explained variations in sapling density and occurrence probability using the second order Akaike Information Criterion (AICc) for small sample size (Burnham et al. 2011). We report the parameter estimates and their 95\% confidence intervals (95\% CIs) obtained with the model that best fitted variations in sapling density and occurrence probability, namely the one with a $\Delta$ AICc $<2$ (Burnham et al. 2011). We conducted all analyses in the R statistical environment (v. 3.5.1, R Core Team 2018) and used $P=0.05$ as a threshold for significance.

\section{Results}

The model, including the interaction between the regenerating tolerant hardwood species and the residual merchantable basal area $\left(\mathrm{m}^{2} \mathrm{ha}^{-1}\right)$ of the stand (after harvesting), as well as the interaction between the regenerating tolerant hardwoods and the percent of hardwoods in the original stand (before harvesting), was the best to explain variations in sapling density (stems $\mathrm{ha}^{-1}$ ) and occurrence probability variation of American beech and sugar maple (Table 1; Table S2, Appendix 1). 
Table 1. Model selection for the prediction of the density and occurrence probability of tolerant hardwood saplings in New Brunswick, Canada. The list of models includes the 20 best models selected. The best model (\#8) is shown in bold with the lowest AICc and $\triangle \mathrm{AICc}$ value. The AICc and $\triangle \mathrm{AICc}$ values of all selected candidate models are mentioned in Table S2, Appendix 1

\begin{tabular}{|c|c|c|c|}
\hline Model \# & Model variables & AICc & $\Delta \mathrm{AICc}$ \\
\hline Model 8 & $\mathrm{Sps}^{1 \star B A}$ residual stand ${ }^{2}+\mathrm{Sps}^{\star} \%$ HWD original stand ${ }^{3}$ & 690.96 & 0 \\
\hline Model 59 & Sps $* \%$ HWD original stand & 694.51 & 3.55 \\
\hline Model 9 & Sps $+\%$ HWD original stand + QMD original stand ${ }^{4}$ & 695.80 & 4.83 \\
\hline Model 71 & Sps ${ }^{*}$ BA original stand ${ }^{5}+\mathrm{Sps}^{*} \%$ IHWD original ${ }^{6}$ stand $+\mathrm{Sps} * \% \mathrm{HWD}$ original stand & 696.36 & 5.40 \\
\hline Model 7 & Sps + BA original stand $+\%$ HWD original stand & 696.41 & 5.45 \\
\hline Model 70 & Sps ${ }^{*}$ BA original stand $+\mathrm{Sps}^{*} \% \mathrm{MHWD}$ original stand ${ }^{7}+\mathrm{Sps}^{*} \% \mathrm{HWD}$ original stand & 696.53 & 5.57 \\
\hline Model 69 & Sps ${ }^{*}$ BA original stand + Sps $* \%$ THWD original stand ${ }^{8}+\mathrm{Sps}^{*} \%$ HWD original stand & 696.77 & 5.81 \\
\hline Model 45 & Sps $+\%$ BA removed trees ${ }^{9}+\%$ HWD original stand & 697.05 & 6.09 \\
\hline Model 60 & $\%$ HWD original stand & 697.14 & 6.18 \\
\hline Model 58 & Sps $+\%$ HWD original stand & 697.41 & 6.44 \\
\hline Model 46 & $\mathrm{Sps} * \% \mathrm{BA}$ removed trees $+\mathrm{Sps} * \% \mathrm{HWD}$ original stand & 697.48 & 6.52 \\
\hline Model 27 & Sps $+\%$ HWD original stand + Elevation & 699.73 & 8.77 \\
\hline Model 28 & Sps $* \%$ HWD original stand + Sps $*$ Elevation & 700.66 & 9.70 \\
\hline Model 21 & Sps $+\%$ HWD original stand + TPI ${ }^{10}$ & 701.35 & 10.39 \\
\hline Model 91 & Sps $+\%$ BA removed trees $+\%$ MHWD original stand $+\%$ HWD original stand & 701.39 & 10.43 \\
\hline Model 90 & Sps $+\%$ BA removed trees $+\%$ THWD original stand $+\%$ HWD original stand & 701.54 & 10.58 \\
\hline Model 92 & Sps $+\%$ BA removed trees + \% IHWD original stand + \% HWD original stand & 701.72 & 10.76 \\
\hline Model 22 & Sps $* \%$ HWD original stand + Sps $*$ TPI & 702.82 & 11.86 \\
\hline Model 30 & Sps ${ }^{\star} \mathrm{QMD}$ original stand + Sps ${ }^{\star}$ Elevation & 703.34 & 12.38 \\
\hline Model 95 & Sps $* \%$ BA removed tree + Sps $* \%$ IHWD original stand + Sps $* \%$ HWD original stand & 703.71 & 12.75 \\
\hline
\end{tabular}

${ }^{1}$ Species; ${ }^{2}$ Residual merchantable basal area $\left(\mathrm{m}^{2}\right.$ ha $\left.{ }^{-1}\right) ;{ }^{3}$ Percent of hardwoods in the original stand; ${ }^{4}$ Quadratic mean diameter of merchantable trees in the original stand before harvest $(\mathrm{cm}) ;{ }^{5}$ Total basal area of the original stand $\left(\mathrm{m}^{2} \mathrm{ha}^{-1}\right) ;{ }^{6}$ Percent of intolerant hardwoods in the original stand; ${ }^{7}$ Percent of mid-tolerant hardwoods in the original stand; ${ }^{8}$ Percent of tolerant hardwoods in the original stand; ${ }^{9}$ Percent of merchantable basal area removed; ${ }^{10}$ Topographic index.

\section{Sapling density}

We observed a significant effect of the residual merchantable basal area on sugar maple sapling density, but the effect was not significant for American beech (Table 2). The sapling density of sugar maple increased with increasing merchantable residual basal area, which ranged from 1 to $32 \mathrm{~m}^{2}$ $\mathrm{ha}^{-1}$ across the PSPs (Fig. 2), corresponding respectively to $4 \%$ and $88 \%$ of the total merchantable basal area. Although there appeared to be a declining trend for American beech for these sample data (Fig. 2), this was not significant.

We also observed a significant effect of the percent of hardwoods in the original stand on sugar maple and American beech sapling density (Table 2). Sapling density increased with the percent of hardwoods in the original stand (Fig. 3). However, sapling density of American beech was higher than those of sugar maple in original stands dominated by hardwoods before harvesting, especially in original stands with a percent of hardwoods greater than $75 \%$ (Fig. 3).

\section{Sapling occurrence probability}

We found a significant effect of the percent of hardwoods in the original stand on the occurrence probability of tolerant hardwood saplings (Table 2). The occurrence probability increased as the percent of hardwoods in the original stand rose (Fig. 4). The occurrence probability of American beech saplings was higher than sugar maple occurrence probability, independent from percent of hardwoods in the original stand (Fig. 4). However, we did not detect any significant effect of the residual merchantable basal area on occurrence probability of sugar maple and American beech saplings (Table 2).

\section{Discussion}

Several studies of the Acadian forest of New Brunswick have found that the partial opening of the canopy after harvesting and the percent of hardwoods in the stand can influence processes underlying forest dynamics such as the recruitment of stems into the merchantable cohort (Forget et al. 2007; Li et al. 2011; Baral et al. 2016). In fact, our analyses showed that sapling density and occurrence probability of tolerant hardwood saplings increased with the initial proportion (before harvesting) of hardwoods in the plot. In addition, the density of sugar maple saplings increased slightly with the residual merchantable basal area (after harvesting). These results partially confirm our first prediction that the variation in sapling density and occurrence would be best explained by treatment intensity (via the residual merchantable basal area). Contradictory to our second prediction though, American beech saplings were more abundant than sugar maple in plots with low basal area after harvesting. We discuss in turn the implications of our results for the density and occurrence probability, respectively, of tolerant hardwood saplings.

\section{Sapling density}

Despite the shade tolerance of sugar maple, several studies have reported that the establishment of this species is favored by partial opening of the canopy through harvesting; its density generally increases with light availability (Forget et al. 2007; Baral et al. 2016). Here, we observed that the sapling density of sugar maple increased with increasing merchantable residual basal area of the stand after harvesting. This suggests that, within the range of harvesting intensities 
Table 2. Summary and coefficient (Coef.) estimates for the density (log link function) and the occurrence probability (logit link function) of saplings obtained with the best predictive model for tolerant hardwood species in New Brunswick, Canada

\begin{tabular}{lcrrr}
\hline Predictors & Coef. estimates & SE & t-value & p-value $^{\mathbf{3}}$ \\
\hline Sapling density & & & & \\
$\quad$ Intercept & 0.470 & 0.807 & 0.583 & 0.560 \\
$\quad$ American beech $\times$ Residual BA ${ }^{1}$ & -0.023 & 0.022 & -1.020 & 0.307 \\
$\quad$ Sugar maple $\times$ Residual BA & 0.072 & 0.027 & 2.675 & $\mathbf{0 . 0 0 7}$ \\
American beech $\times$ \%WD original stand ${ }^{2}$ & 0.049 & 0.009 & 5.387 & $<\mathbf{0 . 0 0 1}$ \\
Sugar maple $\times$ HWD original stand & 0.031 & 0.008 & 3.812 & $<\mathbf{0 . 0 0 1}$ \\
& & & & \\
Occurrence probability of saplings & & & & \\
Intercept & 1.338 & 1.079 & 1.240 & 0.214 \\
American beech $\times$ Residual BA & 0.065 & 0.051 & 1.263 & 0.206 \\
Sugar maple $\times$ Residual BA & 0.077 & 0.043 & 1.792 & 0.073 \\
American beech $\times$ \% HWD original stand & -0.044 & 0.016 & -2.710 & $\mathbf{0 . 0 0 6}$ \\
Sugar maple $\times$ \%WD original stand & -0.031 & 0.014 & -2.274 & $\mathbf{0 . 0 2 2}$ \\
\hline
\end{tabular}

${ }^{1}$ Residual merchantable basal area $\left(\mathrm{m}^{2} \mathrm{ha}^{-1}\right)$

${ }^{2}$ Percent of hardwoods in the original stand (\%)

${ }^{3}$ Values in bold type indicate significance at $P=0.05$

included in our database, canopy opening was sufficient to trigger a positive response in sapling establishment. The increase in basal area might have reduced light levels in the understory such that the growth of fast-growing competing species could have been limited (Thiffault et al. 2015). However, no significant effect was observed for the sapling density of American beech. Hence, several studies recommend the application of partial harvest in stands with an abundance of pre-established sugar maple regeneration in order to increase their abundance after harvesting (Nyland et al. 2006; Kershaw et al. 2012). Under these conditions, the density of sugar maple saplings can exceed that of American beech (Nolet et al. 2008; Danyagri et al. 2019).

Also, we observed a positive effect of increasing percentage of hardwoods in the original stand on sapling density, especially on sapling density of American beech. The percentage of hardwoods in the stands can have a direct influence on the regeneration of tolerant hardwoods as it can influence light availability reaching the understory by influencing the canopy cover (Nyland 2016). Due to its high shade-tolerance, the density of American beech saplings is more strongly influenced by canopy closure (Nolet et al. 2008 , 2015), particularly in stands with a high percentage of hardwoods. Indeed, American beech has a higher growth rate (high leaf display efficiency) and more efficient reproduction than sugar maple under a closed canopy characterized by low light availability (Canham 1988). Under these conditions, the density of American beech saplings exceeds that of sugar maple (Nolet et al. 2015).

\section{Sapling occurrence probability}

Although the probability of occurrence of tolerant hardwood saplings increased with increasing percentage of hardwoods in the original stand, the occurrence probability of American beech saplings was higher than that of sugar maple. Previous studies have reported that the difference between species in the response of sapling occurrence is related to several factors, especially the ecological and physiological requirements

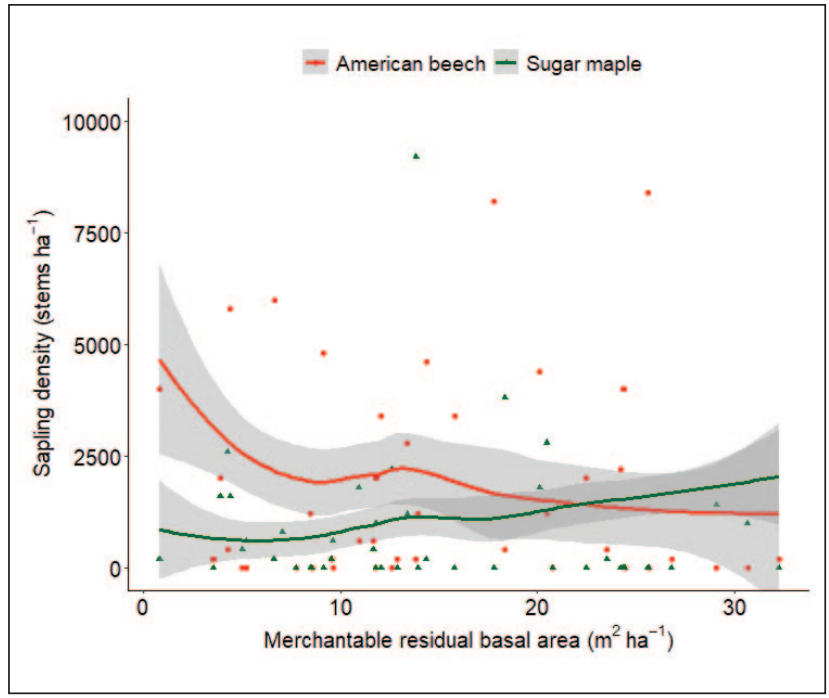

Fig. 2. Sapling density of tolerant hardwoods (stems $h a^{-1}$ ) as a function of merchantable residual basal area $\left(\mathrm{m}^{2} \mathrm{ha}^{-1}\right)$. Raw values for each species and plots are shown along with the curves and their 95\% confidence intervals predicted by the best-fitting model for each species.

of each tolerant hardwood species (Nyland et al. 2006; Nyland 2016), site environmental conditions (Grime and Hunt 1975; Walters and Reich 1996) such as fertility, light availability, and the presence of interspecific competition within the stand (Seymour 1992). In general, sugar maple saplings are frequent on fertile sites with a partial canopy opening that increases light availability, and less frequent under dense forest cover (Forget et al. 2007; Nolet et al. 2008; Baral et al. 2016). However, American beech saplings are more frequent under dense forest cover due to their higher tolerance to shade (Canham 1988; Beaudet et al. 1999; Nolet 


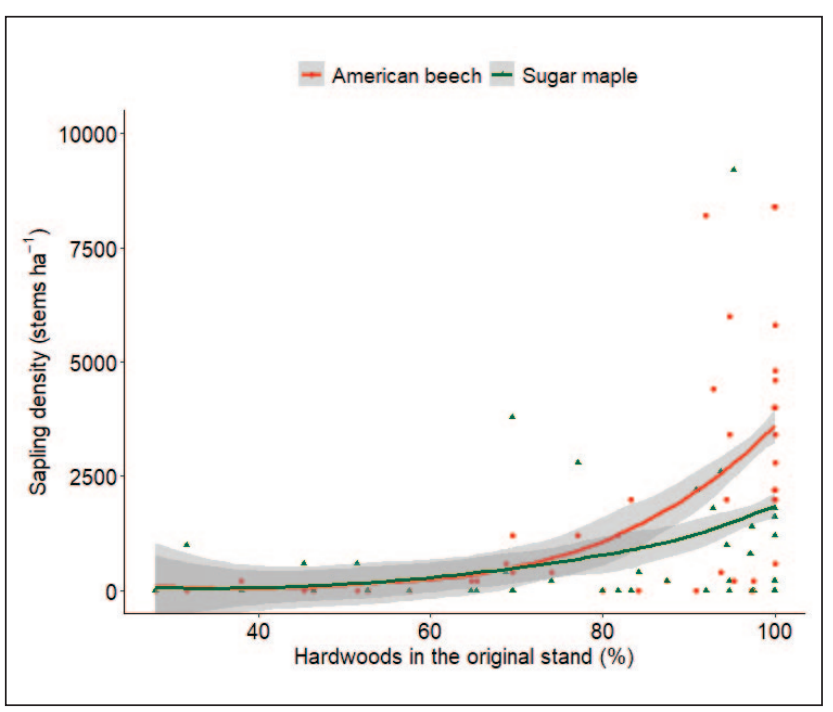

Fig. 3. Sapling density of tolerant hardwoods (stems ha' ${ }^{-1}$ ) as a function of the percent (\%) of hardwoods in the original stand. Raw values for each species and plots are shown along with the curves and their $95 \%$ confidence intervals predicted by the bestfitting model for each species.

et al. 2008, 2015). The occurrence of tolerant hardwood regeneration can also be influenced by other factors not addressed in this study, such as browsing by large herbivores (Bose et al. 2017).

\section{Study limitations}

Our study was limited by its small sample size $(n=43)$, which restricts the inference potential of the results compared to studies based on more extensive sampling designs (Bataineh et al. 2013; Nolet et al. 2015; Bose et al. 2017). This limits our capacity to identify the factors driving regeneration success across a large gradient of conditions. We therefore recommend increasing the number of sample plots to confirm the patterns found for each species and reach more comprehensive conclusions about the most important factors explaining variations in density and occurrence of tolerant hardwood saplings.

In spite of these limitations, our study addresses the response of tolerant hardwood saplings 14 years after harvest. For future research, it would be useful to evaluate the response of saplings over shorter periods, notably two, five and 10 years after harvest through continuous regeneration monitoring. This information would improve our understanding of the regeneration dynamics of tolerant hardwoods after harvest over short-, medium- and long-terms. It also would be relevant to evaluate the density and occurrence of other species groups such as mid-tolerant hardwoods (yellow birch, red maple), intolerant hardwoods (white birch, trembling aspen) and softwood species. These species groups could have a commercial interest to forest managers and, at the same time, may compete with tolerant hardwoods for site resources (e.g., light, nutrients) and influence their density and occurrence (Tubbs 1973; Burns and Honkala 1990; Hane 2003; Hane et al. 2003).

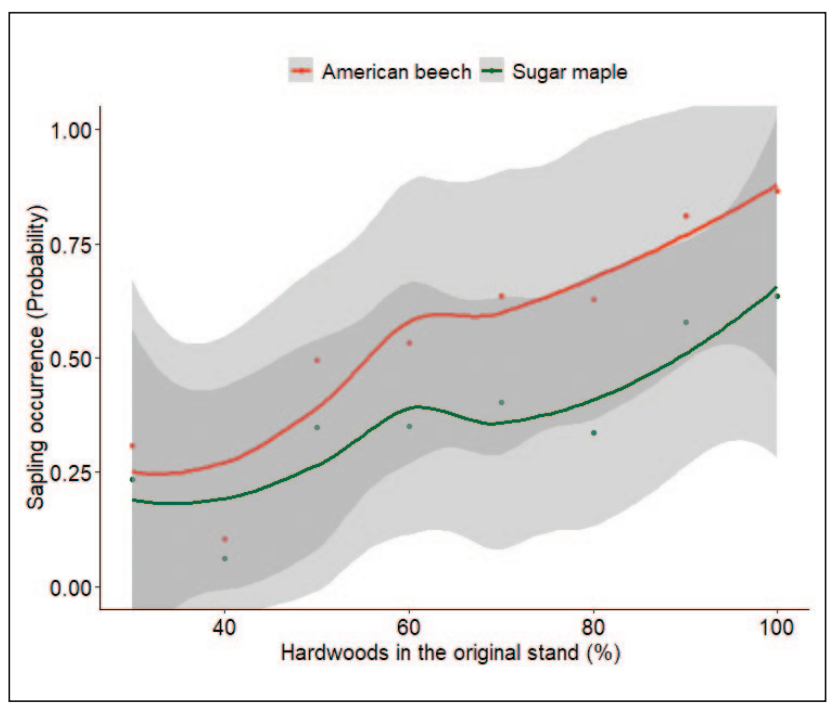

Fig. 4. Occurrence probability of tolerant hardwood saplings as a function of the percent classes (30\% to 100\%) of hardwoods in the original stand. Occurrence probability values for each percent classes are shown along with the curves and their 95\% confidence intervals predicted by the best-fitting model for each species.

\section{Conclusion}

In this study, we examined the effects of silvicultural, environmental, and ecological factors on sapling density and occurrence variability of two commercial tolerant hardwood species in New Brunswick: American beech and sugar maple. Despite its limitations, our study demonstrated that the variation in density and occurrence probability was best explained by treatment intensity expressed as merchantable residual basal area (after harvesting), and by the percent of hardwoods in the original stand. Also, in contradiction to our predictions, we found that American beech saplings seemed more abundant than sugar maple in plots with low basal area after harvesting (plots with low harvesting intensity).

The regeneration of tolerant hardwood stands is an important issue in the management of the Acadian forests of eastern North America which provide a range of economic, environmental and social services (Loo and Ives 2003; Weaver et al. 2009). Improving our understanding of the factors influencing the regeneration and productivity of these forests is essential to optimize their services and ensure their sustainability (Loo and Ives 2003; Salonius 2007). Future research should focus on evaluating the effects of site fertility and the degree of interspecific competition between tolerant hardwoods and other hardwood groups co-existing in the stand on density and occurrence variability. Efforts also should be invested in evaluating the regeneration dynamics of tolerant hardwoods after harvest in the short-, mediumand long-term.

\section{Acknowledgements}

We are grateful to J.D. Irving, Limited for sharing the dataset used in this study and to the University of New Brunswick, (Dave MacLean team), for initiating the study 18 years ago and for sharing the establishment and remeasurement data. We are 
also indebted to the editor and anonymous reviewers who provided constructive advice on an earlier version of this work.

\section{References}

Angers, V. A., C. Messier, M. Beaudet and A. Leduc. 2005. Comparing composition and structure in old-growth and harvested (selection and diameter-limit cuts) northern hardwood stands in Quebec. For. Ecol. Manag. 217(2): 275-293. doi:10.1016/j.foreco. 2005.06.008.

Aldirawi, H., J. Yang and A. A. Metwally. 2019. Identifying Appropriate Probabilistic Models for Sparse Discrete Omics Data. In: 2019 IEEE EMBS International Conference on Biomedical Health Informatics (BHI) 1 4. doi:10.1109/BHI.2019.8834661.

Baral, S. K., G. Danyagri, M. Girouard, F. Hébert and G. Pelletier. 2016. Effects of suppression history on growth response and stem quality of extant northern hardwoods following partial harvests. For. Ecol. Manag. 372: 236-246. doi:10.1016/j.foreco.2016.04.023. Bataineh, M., L. Kenefic, A. Weiskittel, R. Wagner and J. Brissette. 2013. Influence of partial harvesting and site factors on the abundance and composition of natural regeneration in the Acadian Forest of Maine, USA. For. Ecol. Manag. 306: 96-106. doi:10.1016/ j.foreco.2013.06.016.

Beaudet, M., C. Messier and C. D. Canham. 2002. Predictions of understorey light conditions in northern hardwood forests following parameterization, sensitivity analysis, and tests of the SORTIE light model. For. Ecol. Manag. 165(1): 235-248. doi:10.1016/S03781127(01)00621-1.

Beaudet, M., C. Messier, D. Paré, J. Brisson and Y. Bergeron. 1999. Possible mechanisms of sugar maple regeneration failure and replacement by beech in the Boisé-des-Muir old-growth forest, Québec. Écoscience 6(2): 264-271. doi:10.1080/11956860.1999. 11682527.

Betts, M. G., S. E. Franklin and R. G. Taylor. 2003. Interpretation of landscape pattern and habitat change for local indicator species using satellite imagery and geographic information system data in New Brunswick, Canada. Can. J. For. Res. 33(10): 1821-1831. doi:10.1139/x03-104.

Beyeler, J. 2002. Research on forestry practices to sustain the Acadian Forest in Nova Scotia. For. Chron. 78(1): 84-85. doi:10.5558/ tfc78084-1

Bose, A. K., B. D. Harvey and S. Brais. 2014. Sapling recruitment and mortality dynamics following partial harvesting in aspen-dominated mixedwoods in eastern Canada. For. Ecol. Manag. 329: $37-$ 48. doi:10.1016/j.foreco.2014.06.004.

Bose, A. K., A. Weiskittel and R.G. Wagner. 2017. Occurrence, pattern of change, and factors associated with American beechdominance in stands of the northeastern USA forest. For. Ecol. Manag. 392: 202-212. doi:10.1016/j.foreco.2017.03.003.

Burnham, K. P., D. R. Anderson, and K. P. Huyvaert. 2011. AIC model selection and multi-model inference in behavioral ecology: Some background, observations, and comparisons. Behav. Ecol. Sociobiol. 65(1): 23-35. doi:10.1007/s00265-010-1029-6.

Burns, R. M., B. H. Honkala and T. Coordinators. 1990. Silvics of North America: Volume 2. Hardwoods. USDA For. Serv. Agriculture Handbook 654, 876. https://www.fs.usda.gov/treesearch/ pubs/1548. $876 \mathrm{pp}$.

Canham, C. D. 1988. Growth and canopy architecture of shade-tolerant trees: Response to canopy gaps. Ecology 69(3): 786-795. doi:10.2307/1941027

Carle, J. and P. Holmgren. 2003. Definitions related to planted forests. In: UNFF Intercessional Expert Meeting on the role of planted forests in sustainable forest management. pp. 329-343.

Chapin, F. S., T. V. Callaghan, Y. Bergeron, M. Fukuda, J. F. Johnstone, G. Juday and S. A. Zimov. 2004. Global change and the boreal forest: Thresholds, shifting states or gradual change? AMBIO: J. Hum. Environ. 33(6): 361-365. doi:10.1579/0044-7447-33.6.361.
Coates, K. D. and P. J. Burton. 1997. A gap-based approach for development of silvicultural systems to address ecosystem management objectives. For. Ecol. Manag. 99(3): 337-354. doi:10.1016/ S0378-1127(97)00113-8.

Cunningham, R. B. and D. B. Lindenmayer. 2005. Modeling count data of rare species: Some statistical issues. Ecology 86(5): 1135-1142. doi:10.1890/04-0589.

Danyagri, G., S. K. Baral and G. Pelletier. 2019. Effects of disturbance and site factors on sapling dynamics and species diversity in northern hardwood stands. For. Ecol. Manag. 444: 225-234. doi:10.1016/j.foreco.2019.04.041.

Danyagri, G., Baral, S. K., Girouard M., H. G. Adégbidi, and G. Pelletier. 2017. The role of advanced regeneration at time of partial harvest on tolerant hardwood stands development. Can. J. For. Res. 47(10): 1410-1417. doi:10.1139/cjfr-2017-0134.

Dore, M. H. I. 2005. Climate change and changes in global precipitation patterns: What do we know? Environ. Int. 31(8): 1167-1181. doi:10.1016/j.envint.2005.03.004

Dracup, E. C. and D.A. MacLean. 2018. Partial harvest to reduce occurrence of American beech affected by beech bark disease: 10 year results. Forestry: Int. J. For. Res. 91(1): 73-82. doi:10.1093/ forestry/cpx033.

Dullinger, S., T. Dirnböck and G. Grabherr. 2004. Modelling climate change-driven treeline shifts: Relative effects of temperature increase, dispersal and invasibility. J. Ecol. 92(2): 241-252. doi:10.1111/j.0022-0477.2004.00872.x.

Environment and Climate Change Canada. 2020. Canadian climate normals. http://climate.weather.gc.ca/climate_normals/ index_e.html.

Erdle, T. and J. Pollard. 2002. Are plantations changing the tree species composition of New Brunswick's forest? For. Chron. 78(6): 812-821. doi:10.5558/tfc78812-6.

Etheridge, D. A., D. A. MacLean, R. G. Wagner and J. S. Wilson. 2005. Changes in landscape composition and stand structure from 1945-2002 on an industrial forest in New Brunswick, Canada. Can. J. For. Res. 35(8): 1965-1977. doi:10.1139/x05-110.

Forget, E., P. Nolet, F. Doyon, S. Delagrange and Y. Jardon. 2007. Ten-year response of northern hardwood stands to commercial selection cutting in southern Quebec, Canada. For. Ecol. Manag. 242(2): 764-775. doi:10.1016/j.foreco.2007.02.010.

Fortin, M. and J. DeBlois. 2007. Modeling tree recruitment with zero-inflated models: The example of hardwood stands in Southern Québec, Canada. For. Sci. 53(4): 529-539. doi:10.1093/ forestscience/53.4.529.

Griffin, J. M., G. M. Lovett, M. A. Arthur and K. C. Weathers. 2003. The distribution and severity of beech bark disease in the Catskill Mountains, N.Y. Can. J. For. Res. 33(9): 1754-1760. doi: 10.1139/x03-093.

Grime, J. P. and R. Hunt. 1975. Relative Growth-Rate: Its range and adaptive significance in a local flora. J. Ecol. 63(2): 393-422. JSTOR. doi: $10.2307 / 2258728$

Hall, D. B. 2000. Zero-inflated Poisson and binomial regression with random effects: A case study. Biometrics 56(4): 1030-1039. doi:10.1111/j.0006-341X.2000.01030.x.

Hane, E. N. 2003. Indirect effects of beech bark disease on sugar maple seedling survival. Can. J. For. Res. 33(5): 807-813. doi:10.1139/x03-008.

Hane, E. N., S. P. Hamburg, A. L. Barber and J. A. Plaut. 2003. Phytotoxicity of American beech leaf leachate to sugar maple seedlings in a greenhouse experiment. Can. J. For. Res. 33(5): 814821. doi: $10.1139 / \mathrm{x} 03-028$.

Hanson, J. J., C. G. Lorimer and C. R. Halpin. 2011. Predicting long-term sapling dynamics and canopy recruitment in northern hardwood forests. Can. J. For. Res. 41(5): 903-919. doi:10.1139/x11014. Havreljuk, F., A. Achim, D. Auty, S. Bédard and D. Pothier. 2014. Integrating standing value estimations into tree marking guidelines to meet wood supply objectives. Can. J. For. Res. 44(7): 750-759. doi:10.1139/cjfr-2013-0407. 
Hennigar, C., A. Weiskittel, H. L. Allen and D. A. MacLean. 2016. Development and evaluation of a biomass increment based index for site productivity. Can. J. For. Res. 47(3): 400-410. doi:10.1139/ cifr-2016-0330.

Jackman, S. 2008. pscl: Classes and Methods for R Developed in the Political Science Computational Laboratory, Stanford University. Department of Political Science, Stanford University, Stanford, California. R package version 0.95. http://CRAN.R-project.org/ package $=$ pscl.

Jenkins, M. A. and G. R. Parker. 2001. Woody species composition of disturbed forests in intermittent stream bottomlands of southern Indiana. J. Torrey Bot. Soc. 128(2): 165-175. JSTOR. doi:10.2307/ 3088738 .

Kershaw, J. A., M. Krasowski, T. Erdle, J. Golding, L. Salmon, M. Lavigne and A. Taylor. 2012. Response of tolerant hardwood stands to partial-cut harvesting in the Acadian forest: A synthesis of current knowledge and future perspectives. Unpublished Report. Tolerant Hardwood Task Force: New Brunswick Department of Natural Resources, 67. doi:10.13140/RG.2.2.20116.71044.

Kirilenko, A. P. and R. A. Sedjo. 2007. Climate change impacts on forestry. Proc. Natl. Acad. Sci. 104(50): 19697-19702. doi:10.1073/ nas.0701424104.

Klopcic, M., A. Poljanec and A. Boncina. 2012. Modelling natural recruitment of European beech (Fagus sylvatica L.). For. Ecol. Manag. 284: 142-151. doi:10.1016/j.foreco.2012.07.049.

Kozlowski, T. T. 2002. Physiological ecology of natural regeneration of harvested and disturbed forest stands: Implications for forest management. For. Ecol. Manag. 158(1): 195-221. doi:10.1016/ S0378-1127(00)00712-X.

Leak, W. B. and P. E. Sendak. 2002. Field note-Changes in species, grade, and structure over 48 years in a managed New England northern hardwood stand. North. J. Appl. For. 19(1): 25-28. doi:10.1093/njaf/19.1.25.

Li, R., A. R. Weiskittel and J. A. Kershaw. 2011. Modeling annualized occurrence, frequency, and composition of ingrowth using mixed-effects zero-inflated models and permanent plots in the Acadian Forest Region of North America. Can. J. For. Res. 41(10): 2077-2089. doi:10.1139/x11-117.

Liu, J. and P. S. Ashton. 1998. FORMOSAIC: An individual-based spatially explicit model for simulating forest dynamics in landscape mosaics. Ecol. Modell. 106(2): 177-200. doi:10.1016/S03043800(97)00191-9.

Loo, J. and N. Ives. 2003. The Acadian forest: Historical condition and human impacts. For. Chron. 79(3): 462-474. doi:10.5558/ tfc79462-3.

MacDonald, G. B. and D. J. Thompson. 2003. Responses of planted conifers and natural hardwood regeneration to harvesting, scalping, and weeding on a boreal mixedwood site. For. Ecol. Manag. 182(1): 213-230. doi:10.1016/S0378-1127(03)00047-1.

MacDonald, G. B., M.L. Cherry and D. J. Thompson. 2004. Effect of harvest intensity on development of natural regeneration and shrubs in an Ontario boreal mixedwood stand. For. Ecol. Manag. 189(1): 207-222. doi:10.1016/j.foreco.2003.08.010.

Maclean, D., L. J. Amos-Binks, G. Adams and G. Pelletier. 2010. Legacy of the Sustainable Forest Management Network. Outcomes of research collaborations among J.D. Irving, Limited, University of New Brunswick, and Université de Moncton. doi:10.7939/ R3JD4PQ05.

Man, R., J. A. Rice and G. B. MacDonald. 2010. Five-year light, vegetation, and regeneration dynamics of boreal mixedwoods following silvicultural treatments to establish productive aspen-spruce mixtures in northeastern Ontario. Can. J. For. Res. 40(8): 15291541. doi:10.1139/X10-088.

McCullagh, P. and J. A. Nelder. 1989. Generalized linear models. Chapman \& Hall/CRC. New York, USA.

Nelson, A. S. and R. G. Wagner. 2014. Spatial coexistence of American beech and sugar maple regeneration in post-harvest northern hardwood forests. Ann. For. Sci. 71(7): 781-789. doi:10.1007/ s13595-014-0376-2.

Nelson, A. S., R. G. Wagner, M. R. Saunders and A. R. Weiskittel. 2013. Influence of management intensity on the productivity of early successional Acadian stands in eastern Maine. Forestry: Int. J. For. Res. 86(1): 79-90. doi:10.1093/forestry/cps064.

Nolet, P., D. Bouffard, F. Doyon and S. Delagrange. 2008. Relationship between canopy disturbance history and current sapling density of Fagus grandifolia and Acer saccharum in a northern hardwood landscape. Can. J. For. Res. 38(2): 216-225. doi:10.1139/ X07-160.

Nolet, P., S. Delagrange, K. Bannon, C. Messier and D. Kneeshaw. 2015. Liming has a limited effect on sugar maple - American beech dynamics compared with beech sapling elimination and canopy opening. Can. J. For. Res. 45(10): 1376-1386. doi:10.1139/cjfr-20150010.

Nyland, R. D. 2016. Silviculture: Concepts and Applications, Third Edition. Waveland Press, Illinois (USA). 704 pp.

Nyland, R. D., A. L. Bashant, K. K. Bohn and J. M. Verostek. 2006. Interference to hardwood regeneration in northeastern North America: Ecological characteristics of American beech, striped maple, and hobblebush. North. J. Appl. For. 23(1): 53-61. doi: 10.1093/njaf/23.1.53.

R Core Team. 2018. R: a language and environment for statistical computing. R Foundation for Statistical Computing, Vienna, Austria. http://www.R-project.org/.

Ribbens, E., J. A. Silander and S. W. Pacala. 1994. Seedling recruitment in forests: Calibrating models to predict patterns of tree seedling dispersion. Ecology 75(6): 1794-1806. doi:10.2307/1939638. Ripley, T., G. Scrimgeour and M. S. Boyce. 2005. Bull trout (Salvelinus confluentus) occurrence and abundance influenced by cumulative industrial developments in a Canadian boreal forest watershed. Can. J. Fish. Aquat. Sci. 62(11): 2431-2442. doi:10.1139/f05-150.

Salmon, L., J. A. K. Jr, A. R. Taylor, M. Krasowski and M. B. Lavigne. 2016. Exploring factors influencing species natural regeneration response following harvesting in the Acadian forests of New Brunswick. Open J. For. 6(3): 199-215. doi:10.4236/ojf.2016.63017. Salonius, P. 2007. Silvicultural discipline to maintain Acadian forest resilience. North. J. Appl. For. 24(2): 91-97. doi:10.1093/njaf/24.2.91. Seymour, R. S. 1992. The red spruce-balsam fir forest of Maine: Evolution of silvicultural practice in response to stand development patterns and disturbances. In: M. J. Kelty, B. C. Larson \& C. D. Oliver (Eds.). The Ecology and Silviculture of Mixed-Species Forests: A Festschrift for David M. Smith (pp. 217-244). Springer Netherlands. doi:10.1007/978-94-015-8052-6_12.

Seymour, R. S., A. S. White and P. G. deMaynadier. 2002. Natural disturbance regimes in northeastern North America - evaluating silvicultural systems using natural scales and frequencies. For. Ecol. Manag. 155(1): 357-367. doi:10.1016/S0378-1127(01)00572-2.

Spence, C. E. and D. A. MacLean. 2012. Regeneration and stand development following a spruce budworm outbreak, spruce budworm inspired harvest, and salvage harvest. Can. J. For. Res. 42(10): 1759-1770. doi:10.1139/x2012-121.

Taylor, A. R., Y. Boulanger, D. T. Price, D. Cyr, E. McGarrigle, W. Rammer and J. A. Kershaw. 2017. Rapid 21st century climate change projected to shift composition and growth of Canada's Acadian Forest Region. For. Ecol. Manag. 405: 284-294. doi:10.1016/j.foreco.2017.07.033.

Thiffault, N., L. Coll and D.F. Jacobs. 2015. Natural regeneration after harvesting. In: Routledge Handbook of Forest Ecology. K.S.-H. Peh and R.T. Corlett and Y. Bergeron (Eds.). Routledge, Oxford, UK. pp. 371-384.

Thomas, G., L. R. Nakamura, R. A. Moral and C. G. B. Demétrio. 2018. Modeling data with zero inflation and overdispersion using GAMLSSs. arXiv:1810.02618 [stat]. doi:arXiv:1810.02618. 
Tubbs, C. H. 1973. Allelopathic relationship between yellow birch and sugar maple seedlings. For. Sci. 19(2): 139-145. doi:10.1093/ forestscience/19.2.139.

Walters, M. B. and P. B. Reich. 1996. Are shade tolerance, survival, and growth linked? Low light and nitrogen effects on hardwood seedlings. Ecology 77(3): 841-853. doi:10.2307/2265505.

Wang, L., H. Aldirawi and J. Yang. 2020. Identifying zero-inflated distributions with a new R Package IZID. Communications in Inf. Syst. 20(1): 23-44. doi:10.4310/CIS.2020.v20.n1.a2.

Weaver, J. K., L. S. Kenefic, R. S. Seymour and J. C. Brissette. 2009. Decaying wood and tree regeneration in the Acadian Forest of Maine, USA. For. Ecol. Manag. 257(7): 1623-1628. doi:10.1016/ j.foreco.2009.01.023.

Williamson, T. B., S. J. Colombo, P. N. Duinker, P. A. Gray, R. J. Hennessey, D. Houle, M. H. Johnston, A. E. Ogden and D. L. Spittlehouse. 2009. Climate change and Canada's forests : From impacts to adaptation. Natural Resources Canada, Canadian Forest Service, Northern Forestry Centre. http://cfs.nrcan.gc.ca/publications?id=29616. $112 \mathrm{p}$.
Yang, Q., F.-R. Meng, C. P.-A. Bourque and Z. Zhao. 2017. Production of high-resolution forest-ecosite maps based on model predictions of soil moisture and nutrient regimes over a large forested area. Sci. Rep. 7(1):1-13. doi:10.1038/s41598-017-11381-z.

Zeileis, A., C. Kleiber and S. Jackman. 2008. Regression models for count data in R. J. Stat. Softw. 27(8): 1-25. doi:10.18637/jss.v027.i08. Zelazny, V. F., New Brunswick, Department of Natural Resources, New Brunswick, Ecosystem Classification Working Group. 2007. Our landscape heritage: The story of ecological land classification in New Brunswick. (2nd edition). New Brunswick Department of Natural Resources. 404 pp. 
Table S1. List of 104 candidate models for AICc selection used for predicting the density and occurrence of tolerant hardwood saplings

\begin{tabular}{|c|c|c|c|}
\hline Model\# & Model variables and interactions & Model\# & Model variables and interactions \\
\hline Null model & - & Model 30 & Sps ${ }^{\star} \mathrm{QMD}$ original stand + Sps ${ }^{\star}$ Elevation \\
\hline Global model & 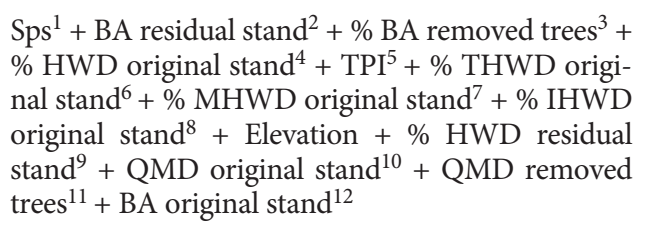 & Model 31 & $\begin{array}{l}\mathrm{Sps}+\mathrm{BA} \text { residual stand }+\% \mathrm{BA} \text { removed trees } \\
\mathrm{Sps}{ }^{\star} \mathrm{BA} \text { residual stand }+\mathrm{Sps} * \% \mathrm{BA} \text { removed trees }\end{array}$ \\
\hline Model 1 & $\begin{array}{l}\text { Sps }+ \text { BA residual stand + \% BA removed trees }+\% \\
\text { HWD residual stand }\end{array}$ & $\begin{array}{l}\text { Model } 35 \\
\text { Model } 36\end{array}$ & $\begin{array}{l}\text { Sps }+\% \text { BA removed trees } \\
\text { Sps } * \% \text { BA removed trees }\end{array}$ \\
\hline Model 2 & $\begin{array}{l}\text { Sps }{ }^{*} \text { BA residual stand }+\mathrm{Sps}^{*} \% \text { BA removed trees } \\
+\mathrm{Sps} * \% \text { HWD residual stand }\end{array}$ & Model 37 & Sps $+\%$ BA removed trees + Slope \\
\hline Model 3 & $\begin{array}{l}\text { Sps }+ \text { BA residual stand }+\% \text { BA removed trees }+ \\
\text { QMD removed trees }\end{array}$ & $\begin{array}{l}\text { Model } 38 \\
\text { Model } 39\end{array}$ & $\begin{array}{l}\text { Sps } * \% \text { BA removed trees }+ \text { Sps } * \text { Slope } \\
\text { Sps }+\% \text { BA removed trees }+ \text { TPI }\end{array}$ \\
\hline Model 4 & $\begin{array}{l}\text { Sps }{ }^{*} \mathrm{BA} \text { residual stand }+\mathrm{Sps} * \% \mathrm{BA} \text { removed trees } \\
+\mathrm{Sps} * \mathrm{QMD} \text { removed trees }\end{array}$ & Model 40 & $\begin{array}{l}\text { Sps } * \% \mathrm{BA} \text { removed trees }+\mathrm{Sps} * \mathrm{TPI} \\
\mathrm{Sps}+\% \mathrm{BA} \text { removed trees }+ \text { Elevation }\end{array}$ \\
\hline Model 5 & $\begin{array}{l}\text { Sps + QMD removed trees + \% HWD residual } \\
\text { stand }\end{array}$ & Model 42 & $\mathrm{Sps} * \% \mathrm{BA}$ removed trees $+\mathrm{Sps}{ }^{\star}$ Elevation \\
\hline Model 6 & $\begin{array}{l}\text { Sps }{ }^{*} \mathrm{QMD} \text { removed trees }+\mathrm{Sps} * \% \mathrm{HWD} \text { residual } \\
\text { stand }\end{array}$ & $\begin{array}{l}\text { Model } 43 \\
\text { Model } 44\end{array}$ & $\begin{array}{l}\text { Sps }+\% \mathrm{BA} \text { removed trees }+\mathrm{BGI} \\
\mathrm{Sps} * \% \mathrm{BA} \text { removed trees }+\mathrm{Sps}{ }^{\star} \mathrm{BGI}\end{array}$ \\
\hline Model 7 & Sps + BA original stand $+\%$ HWD original stand & Model 45 & Sps $+\%$ BA removed trees $+\%$ HWD original stand \\
\hline Model 8 & $\begin{array}{l}\text { Sps }{ }^{*} \mathrm{BA} \text { residual stand }+\mathrm{Sps} * \% \text { HWD original } \\
\text { stand }\end{array}$ & Model 46 & $\begin{array}{l}\text { Sps * \% BA removed trees }+ \text { Sps } * \% \text { HWD original } \\
\text { stand }\end{array}$ \\
\hline Model 9 & Sps $+\%$ HWD original stand + QMD original stand & Model 47 & Sps $+\% \mathrm{BA}$ removed trees $+\mathrm{BA}$ original stand \\
\hline Model 10 & $\begin{array}{l}\text { Sps } * \% \text { HWD residual stand }+ \text { Sps } * \text { QMD residual } \\
\text { stand }{ }^{13}\end{array}$ & $\begin{array}{l}\text { Model } 48 \\
\text { Model } 49\end{array}$ & $\begin{array}{l}\text { Sps } * \% \text { BA removed trees }+\mathrm{Sps}^{*} \mathrm{BA} \text { original stand } \\
\text { Sps }+\% \text { BA removed trees }+\mathrm{QMD} \text { original stand }\end{array}$ \\
\hline Model 11 & Sps + DWT ${ }^{14}$ & Model 50 & $\begin{array}{l}\text { Sps } * \% \text { BA removed trees }+\mathrm{Sps}^{\star} \mathrm{QMD} \text { original } \\
\text { stand }\end{array}$ \\
\hline Model 13 & Sps + BGI ${ }^{15}$ & Model 51 & Sps + Slope \\
\hline Model 14 & Sps * BGI & Model 52 & Sps * Slope \\
\hline Model 15 & Sps + TPI + Elevation & Model 53 & Sps + Elevation \\
\hline Model 16 & Sps ${ }^{\star} \mathrm{TPI}+\mathrm{Sps}{ }^{\star}$ Elevation & Model 54 & Sps ${ }^{\star}$ Elevation \\
\hline Model 17 & Sps + Aspect + Slope & Model 55 & Sps ${ }^{\star}$ QMD original stand \\
\hline Model 18 & Sps ${ }^{\star}$ Aspect + Sps $*$ Slope & Model 56 & Sps ${ }^{*} \mathrm{QMD}$ removed trees \\
\hline Model 19 & Sps + BA original stand + TPI & Model 57 & Sps ${ }^{\star} \mathrm{QMD}$ original stand \\
\hline Model 20 & $\mathrm{Sps}{ }^{\star} \mathrm{BA}$ original stand $+\mathrm{Sps}{ }^{\star} \mathrm{TPI}$ & Model 58 & Sps $+\%$ HWD original stand \\
\hline Model 21 & Sps $+\%$ HWD original stand + TPI & Model 59 & Sps $* \%$ HWD original stand \\
\hline Model 22 & Sps $* \%$ HWD original stand + Sps $*$ TPI & Model 60 & $\%$ HWD original stand \\
\hline Model 23 & Sps + QMD original stand + TPI & Model 61 & Sps \\
\hline Model 24 & $\mathrm{Sps}^{\star} \mathrm{QMD}$ original stand $+\mathrm{Sps}{ }^{\star} \mathrm{TPI}$ & Model 62 & Sps + Soil \\
\hline Model 25 & Sps + BA original stand + Elevation & Model 63 & Sps ${ }^{*}$ Soil \\
\hline Model 26 & Sps ${ }^{\star} \mathrm{BA}$ original stand $+\mathrm{Sps}{ }^{\star}$ Elevation & Model 64 & Sps + Ecosite \\
\hline Model 27 & Sps $+\%$ HWD original stand + Elevation & Model 65 & Sps ${ }^{\star}$ Ecosite \\
\hline Model 28 & Sps $* \%$ HWD original stand + Sps $*$ Elevation & Model 66 & Sps + BA original stand $+\%$ THWD original stand \\
\hline Model 29 & Sps + QMD original stand + Elevation & Model 67 & Sps + BA original stand $+\%$ MHWD original stand \\
\hline
\end{tabular}




\section{Model 68} Sps + BA original stand $+\%$ IHWD original stand

Model 69 Sps * BA original stand $+\mathrm{Sps} * \%$ THWD original stand $+\mathrm{Sps} * \%$ HWD original stand

Model 70 Sps * BA original stand + Sps * \% MHWD original stand $+\mathrm{Sps} * \%$ HWD original stand

Model 71 Sps * BA original stand + Sps * \% IHWD original stand + Sps $* \%$ HWD original stand

Model 72 Sps $+\%$ THWD original stand $+\%$ HWD residual stand + QMD residual stand

Model 73 Sps + \% MHWD original stand + \% HWD residual stand + QMD residual stand

Model $74 \quad$ Sps $+\%$ IHWD original stand $+\%$ HWD residual stand + QMD residual stand

Model 75 Sps * \% THWD original stand + Sps * \% HWD residual stand + Sps ${ }^{*} \mathrm{QMD}$ residual stand

Model 76 Sps * \% MHWD original stand + Sps * \% HWD residual stand + Sps ${ }^{*} \mathrm{QMD}$ residual stand

Model 77 Sps * \% IHWD original stand + Sps * \% HWD residual stand $+\mathrm{Sps}^{\star} \mathrm{QMD}$ residual stand

Model 78 Sps $+\%$ THWD original stand $+\%$ HWD original stand + TPI

Model 79 Sps $+\%$ MHWD original stand $+\%$ HWD original stand + TPI

Model $80 \quad$ Sps $+\%$ IHWD original stand $+\%$ HWD original stand + TPI

Model 81 Sps * \% THWD original stand + Sps * \% HWD original stand $+\mathrm{Sps}{ }^{*} \mathrm{TPI}$

Model 82 Sps * \% MHWD original stand + Sps * \% HWD original stand $+\mathrm{Sps} *$ TPI

Model 83 Sps * \% IHWD original stand + Sps * \% HWD original stand + Sps * TPI

Model 84 Sps $+\%$ THWD original stand $+\%$ HWD original stand + Elevation
Model\# Model variables and interactions

Model 85

Sps $+\%$ MHWD original stand $+\%$ HWD original stand + Elevation

Model 86 Sps + \% IHWD original stand + \% HWD original stand + Elevation

Model 87 Sps * \% THWD original stand + Sps * \% HWD original stand $+\mathrm{Sps}{ }^{\star}$ Elevation

Model 88 Sps * \% MHWD original stand $+\mathrm{Sps} * \%$ HWD original stand $+\mathrm{Sps} *$ Elevation

Model 89 Sps * \% IHWD original stand + Sps * \% HWD original stand $+\mathrm{Sps} *$ Elevation

Model 90 Sps $+\%$ BA removed trees $+\%$ THWD original stand $+\%$ HWD original stand

Model 91 Sps $+\%$ BA removed trees $+\%$ MHWD original stand $+\%$ HWD original stand

Model 92 Sps $+\%$ BA removed trees $+\%$ IHWD original stand $+\%$ HWD original stand

Model 93 Sps *\% BA removed trees + Sps * \% THWD original stand $+\mathrm{Sps} * \%$ HWD original stand

Model 94 Sps * \% BA removed trees Sps *\% MHWD original stand $+\mathrm{Sps} * \%$ HWD original stand

Model 95 Sps *\% BA removed tree + Sps * \% IHWD original stand $+\mathrm{Sps} * \%$ HWD original stand

Model 96 Sps + \% THWD original stand

Model 97 Sps + \% MHWD original stand

Model 98 Sps + \% IHWD original stand

Model 99 Sps * \% THWD original stand

Model 100 Sps *\% MHWD original stand

Model 101 Sps * \% IHWD original stand

Model 102 \% THWD original stand

Model 103 \% MHWD original stand

Model 104 \% IHWD original stand

${ }^{1}$ Species

${ }^{2}$ Residual merchantable basal area $\left(\mathrm{m}^{2} \mathrm{ha}^{-1}\right)$

${ }^{3}$ Percent (\%) of merchantable basal area removed

${ }^{4}$ Percent (\%) of hardwoods in the original stand

${ }^{5}$ Topographic index

${ }^{6}$ Percent (\%) of tolerant hardwoods in the original stand

${ }^{7}$ Percent (\%) of mid-tolerant hardwoods in the original stand

${ }^{8}$ Percent (\%) of intolerant hardwoods in the original stand

${ }^{9}$ Percent (\%) of hardwoods in the residual stand

${ }^{10}$ Quadratic mean diameter of merchantable trees in the original stand before harvest $(\mathrm{cm})$

${ }^{11}$ Quadratic mean diameter of the removed merchantable trees after the first harvest $(\mathrm{cm})$

${ }^{12}$ Total basal area of the original stand $\left(\mathrm{m}^{2} \mathrm{ha}^{-1}\right)$

${ }^{13}$ Quadratic mean diameter of the residual merchantable trees after the first harvest $(\mathrm{cm})$

${ }^{14}$ Depth of the water table $(\mathrm{m})$

${ }^{15}$ Biomass growth index 
Table S2. The AICc and $\triangle \mathrm{AIC}$ c values of all selected candidate models used for the prediction of the density and occurrence of tolerant hardwood saplings in New Brunswick, Canada. The best model (\#8) is shown in bold with the lowest AICc and $\triangle$ AICc value.

\begin{tabular}{|c|c|c|c|c|c|c|c|}
\hline Model \# & AICc & $\Delta \mathrm{AICc}$ & df & Model \# & AICc & $\Delta \mathrm{AICc}$ & df \\
\hline Model 8 & 690.96 & 0 & 11 & Model 25 & 712.79 & 21.83 & 9 \\
\hline Model 59 & 694.51 & 3.55 & 7 & Model 82 & 713.00 & 22.03 & 15 \\
\hline Model 9 & 695.80 & 4.83 & 9 & Model 15 & 713.00 & 22.04 & 9 \\
\hline Model 71 & 696.36 & 5.40 & 15 & Model 50 & 713.15 & 22.19 & 11 \\
\hline Model 7 & 696.41 & 5.45 & 9 & Model 26 & 713.17 & 22.21 & 11 \\
\hline Model 70 & 696.53 & 5.57 & 15 & Model 42 & 713.70 & 22.74 & 11 \\
\hline Model 69 & 696.77 & 5.81 & 15 & Model 16 & 713.89 & 22.93 & 11 \\
\hline Model 45 & 697.05 & 6.09 & 9 & Model 35 & 713.99 & 23.03 & 7 \\
\hline Model 60 & 697.14 & 6.18 & 5 & Null model & 714.01 & 23.05 & 3 \\
\hline Model 58 & 697.41 & 6.44 & 7 & Model 1 & 714.07 & 23.11 & 11 \\
\hline Model 46 & 697.48 & 6.52 & 11 & Model 12 & 714.17 & 23.21 & 7 \\
\hline Model 27 & 699.73 & 8.77 & 9 & Model 34 & 714.18 & 23.22 & 7 \\
\hline Model 28 & 700.66 & 9.70 & 11 & Model 67 & 714.21 & 23.25 & 9 \\
\hline Model 21 & 701.35 & 10.39 & 9 & Model 47 & 714.26 & 23.30 & 9 \\
\hline Model 91 & 701.39 & 10.43 & 11 & Model 41 & 714.45 & 23.49 & 9 \\
\hline Model 90 & 701.54 & 10.58 & 11 & Model 77 & 714.55 & 23.59 & 15 \\
\hline Model 92 & 701.72 & 10.76 & 11 & Model 68 & 714.62 & 23.66 & 9 \\
\hline Model 22 & 702.82 & 11.86 & 11 & Model 75 & 715.12 & 24.16 & 15 \\
\hline Model 30 & 703.34 & 12.38 & 11 & Model 98 & 715.15 & 24.19 & 7 \\
\hline Model 95 & 703.71 & 12.75 & 15 & Model 3 & 715.15 & 24.19 & 11 \\
\hline Model 85 & 704.27 & 13.31 & 11 & Model 13 & 715.19 & 24.23 & 7 \\
\hline Model 84 & 704.50 & 13.54 & 11 & Model 72 & 715.27 & 24.31 & 11 \\
\hline Model 86 & 704.83 & 13.8 & 11 & Model 17 & 715.35 & 24.39 & 9 \\
\hline Model 5 & 705.69 & 14.73 & 9 & Model 11 & 715.39 & 24.43 & 7 \\
\hline Model 80 & 705.87 & 14.91 & 11 & Model 97 & 715.52 & 24.55 & 7 \\
\hline Model 79 & 706.24 & 15.27 & 11 & Model 14 & 715.67 & 24.71 & 7 \\
\hline Model 78 & 706.29 & 15.30 & 11 & Model 51 & 715.77 & 24.81 & 7 \\
\hline Model 89 & 706.56 & 15.59 & 15 & Model 36 & 715.81 & 24.85 & 7 \\
\hline Model 56 & 706.7 & 15.78 & 7 & Model 39 & 716.23 & 25.26 & 9 \\
\hline Model 55 & 707.05 & 16.08 & 7 & Model 20 & 716.92 & 25.96 & 11 \\
\hline Model 57 & 707.05 & 16.08 & 7 & Model 31 & 717.07 & 26.11 & 9 \\
\hline Model 93 & 707.38 & 16.42 & 15 & Model 104 & 717.41 & 26.45 & 5 \\
\hline Model 94 & 707.43 & 16.47 & 15 & Model 74 & 717.45 & 26.49 & 11 \\
\hline Model 83 & 707.95 & 16.99 & 15 & Model 2 & 717.48 & 26.52 & 15 \\
\hline Model 23 & 708.10 & 17.14 & 9 & Model 52 & 717.52 & 26.56 & 7 \\
\hline Model 99 & 708.18 & 17.22 & 7 & Model 73 & 717.67 & 26.71 & 11 \\
\hline Model 54 & 709.11 & 18.14 & 7 & Model 62 & 717.83 & 26.87 & 15 \\
\hline Model 49 & 709.17 & 18.21 & 9 & Model 103 & 717.90 & 26.94 & 5 \\
\hline Model 6 & 709.55 & 18.59 & 11 & Model 43 & 718.08 & 27.12 & 9 \\
\hline Model 29 & 709.94 & 18.98 & 9 & Model 37 & 718.69 & 27.73 & 9 \\
\hline Model 10 & 709.98 & 19.02 & 11 & Model 100 & 718.72 & 27.76 & 7 \\
\hline Model 87 & 710.30 & 19.34 & 15 & Model 48 & 718.72 & 27.76 & 11 \\
\hline Model 88 & 710.32 & 19.36 & 15 & Model 101 & 719.90 & 28.94 & 7 \\
\hline Model 96 & 710.49 & 19.50 & 7 & Model 40 & 720.53 & 29.57 & 11 \\
\hline Model 66 & 710.89 & 19.93 & 9 & Model 76 & 720.89 & 29.93 & 15 \\
\hline Model 53 & 710.98 & 20.01 & 7 & Model 32 & 721.10 & 30.14 & 11 \\
\hline Model 61 & 711.36 & 20.40 & 5 & Model 18 & 721.61 & 30.65 & 11 \\
\hline Model 64 & 712.02 & 21.06 & 13 & Model 44 & 722.43 & 31.47 & 11 \\
\hline Model 24 & 712.23 & 21.27 & 11 & Model 4 & 724.12 & 33.16 & 15 \\
\hline Model 81 & 712.37 & 21.41 & 15 & Model 38 & 725.24 & 34.28 & 11 \\
\hline Model 19 & 712.60 & 21.64 & 9 & Global model & 747.37 & 56.41 & 29 \\
\hline Model 102 & 712.65 & 21.69 & 5 & Model 63 & 2825.90 & 2134.94 & 27 \\
\hline Model 33 & 712.65 & 21.69 & 7 & & & & \\
\hline
\end{tabular}




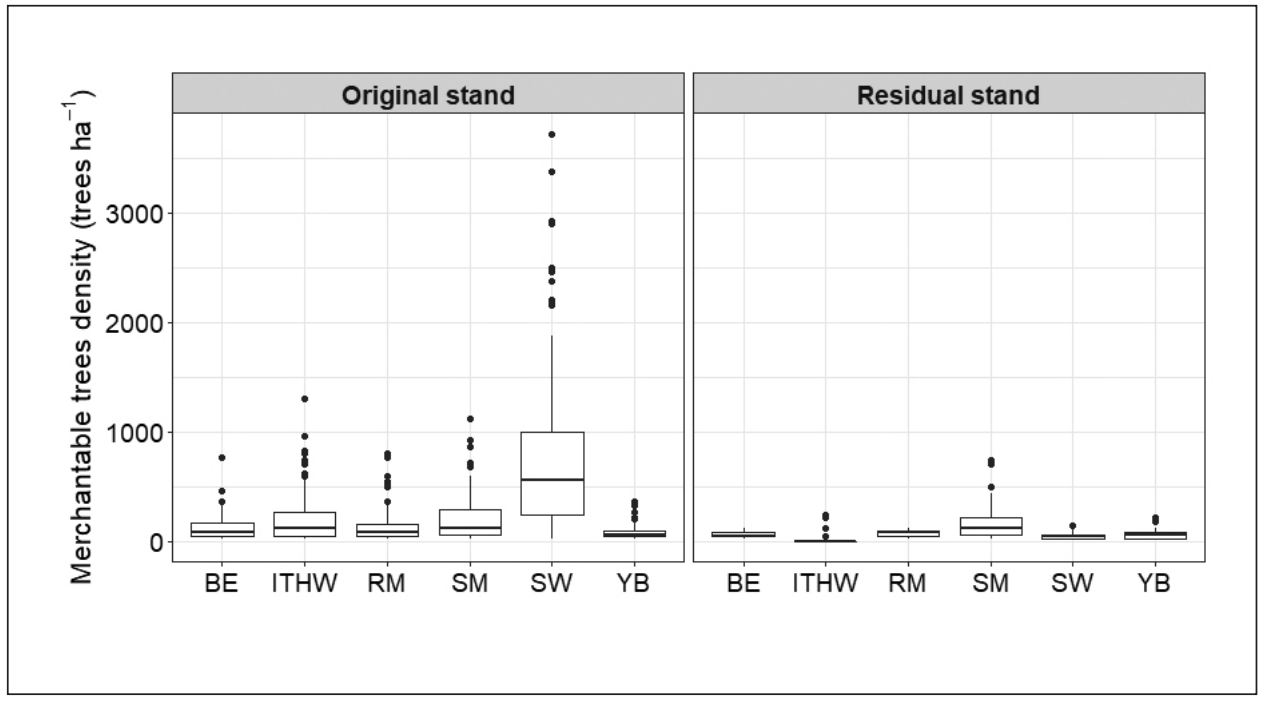

Fig. S1. Box plots showing the variation of trees density (trees ha-1) by species or group of species in the original (before harvesting) and residual stands (after harvesting). BE: American beech; ITHW: intolerant hardwoods (white birch, trembling aspen); RM: red maple; SM: sugar maple; SW: softwood; YB: yellow birch.

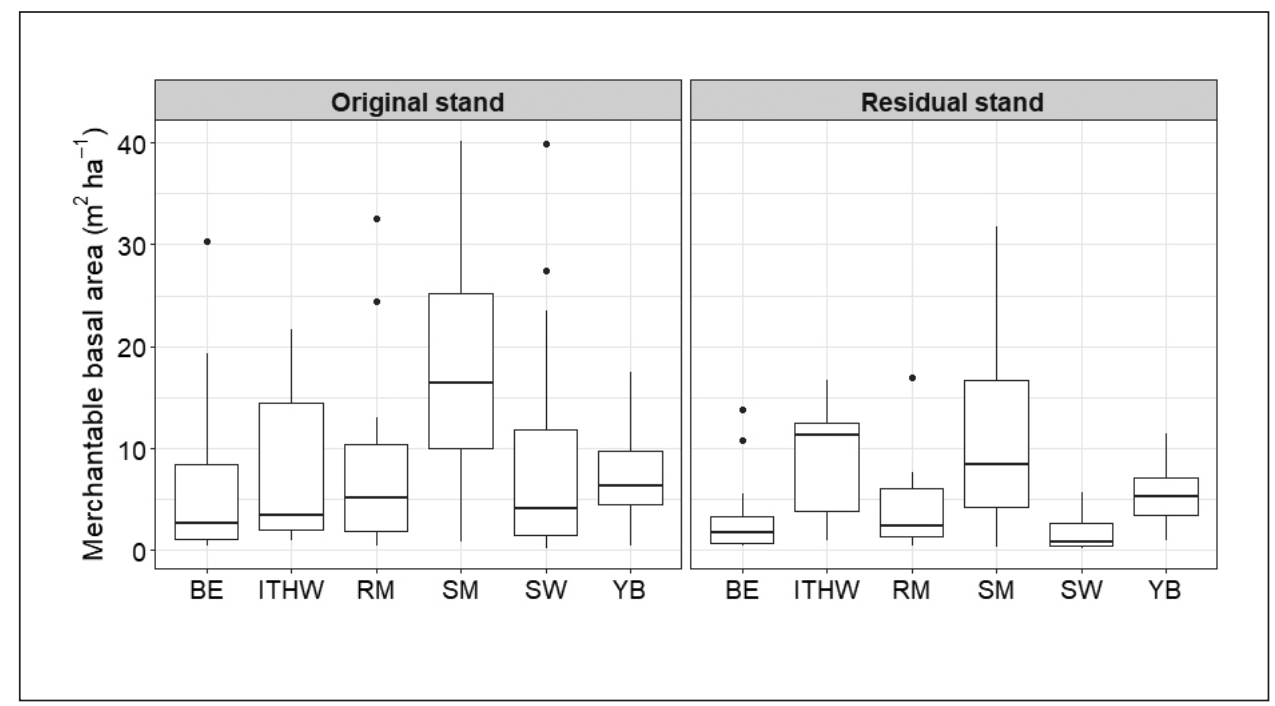

Fig. S2. Box plots showing the variation in merchantable basal area $\left(\mathrm{m}^{2} \mathrm{ha}^{-1}\right)$ by species or group of species in the original (before harvesting) and residual stands (after harvesting). BE: American beech; ITHW: intolerant hardwoods (white birch, trembling aspen); RM: red maple; SM: sugar maple; SW: softwood; YB: yellow birch. 


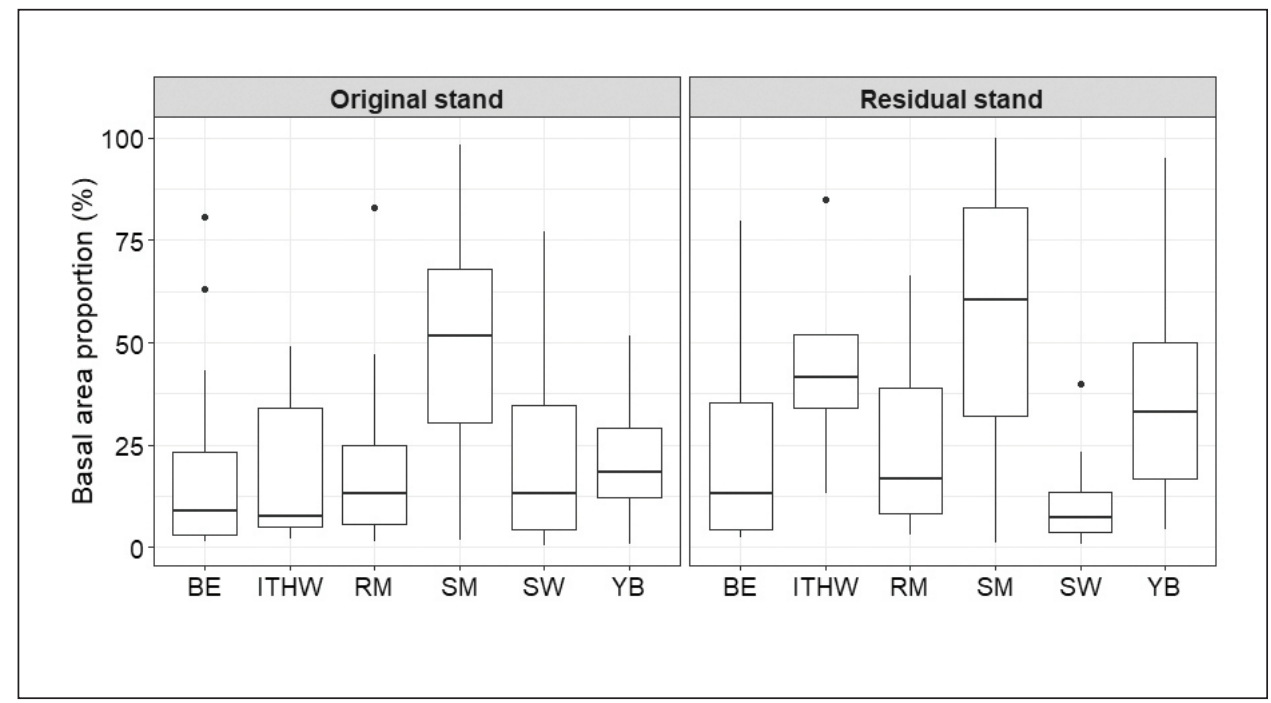

Fig. 53. Box plots showing the variation in the proportion of basal area (\%) for each species or group of species in original (before harvesting) and residual stands (after harvesting). BE: American beech; ITHW: intolerant hardwoods (white birch, trembling aspen); RM: red maple; SM: sugar maple; SW: softwood; YB: yellow birch. 